\title{
ENGAGING WITH CHURCHES TO ADDRESS DEVELOPMENT- RELATED CHALLENGES IN SOLOMON ISLANDS
}

\author{
Ross Cassells ${ }^{1}$
}

\begin{abstract}
Solomon Islands churches, such as the United Church on Choiseul, have developed extensive organisational networks, governance structures, and a local political legitimacy that frequently surpasses that of the state. Well-respected and very influential at village-level, churches are in a strong position to be agents for change. On Choiseul, however, Nukiki village and others are facing significant development-related challenges which they, and the church, do not have the necessary skills to address. Outside assistance is needed to enhance local capacity, and this could be achieved if development agencies engaged in partnerships with the church. In discussing the potential for productive partnerships with churches, this paper focuses on the case of the United Church in Nukiki Village, Choiseul Province.
\end{abstract}

Keywords: Christianity; churches; development; Solomon Islands; Choiseul

\section{INTRODUCTION}

In remote provinces of Solomon Islands, the reach of the state is limited. Geographical isolation and scarce resources are contributing factors, but the isolation of such areas is social as well as political. In provinces such as Choiseul, peoples' identity is found in the kin group relations that underpin their societies. Here, governance is said to be undertaken by traditional leaders (White 2004), but, in reality, this leadership often takes the form of hybrid polities that comprise chiefly and church authority. Such polities have a political legitimacy that the state has yet to gain.

Nukiki, on Choiseul, provides an example of village governance that is politically hybrid in form. Village leadership is, however, primarily church-focused and lacks the skills necessary to address a range of development issues that 
Nukiki is now facing. The Provincial Government also has limited capacity, so if Nukiki is to avoid being overwhelmed by these issues, outside development assistance is needed.

Drawing extensively on ethnographic research conducted in Nukiki in 1991 and 2012 (Cassells 1992 and 2016), as well as my considerable experience as a development practitioner in Solomon Islands, ${ }^{2}$ this paper strengthens arguments advanced elsewhere that advocate the formation of partnerships between churches and external development agencies (see Clarke 2015; Fountain, Bush, and Feener 2015; Marshall 2001; Ver Beek 2000). While it is recognised that such partnerships can be diverse and complex (Bush, Fountain, and Feener 2015), they do have the potential to provide a strength and a legitimacy to development initiatives that has often been difficult to achieve. As such, this paper primarily seeks to engage with development practitioners in order to encourage further discussion and engagement with churches on these matters.

\section{THE NUKIKI CHURCH}

When I first lived in Nukiki in 1991, there was only one church in the village. Part of the United Church of Solomon Islands, which had its origins in the Methodist Mission, ${ }^{3}$ this church was a small leaf house located alongside the entrance to the Talevondo Stream. It had no doors or windows, just an opening through which one entered. The 'floor' was coral sand, and the 'pews' were simple slat benches with no backs. The men sat to the left of the central aisle, and the women to the right. The services were conducted in the Varisi language and, for one who could not understand Varisi, seemed dreadfully long - especially on those uncomfortable benches. But the villagers were kind to me, and the service leader would often announce the hymn number in English for my benefit. Christianity was clearly very important to the villagers of Nukiki; Sunday was for the church, and after the church service it was a day of rest.

Immediately behind the old leaf house church, a new concrete block church was being constructed. It had a concrete floor and a corrugated iron roof. Each of the concrete blocks used in its construction was hand-made. The new church building was truly a labour of love. The coral sand on the beach by Nukiki was unsuitable for concrete so, over many years, the villagers had paddled their canoes to Pavora Bay to collect sand to bring back to Nukiki to make concrete blocks. There was no reef at Pavora Bay, so the beach was exposed to the open sea. As a result the sand was finer, having been ground-down and sifted by the incoming waves, and this made it suitable material for making concrete. The villagers had obtained several steel moulds that they used to make concrete 
blocks. They would mix the sand with cement on a flat piece of galvanised iron before pouring the wet concrete into the moulds. Thus, block by block the walls of the church were raised. Their dedication was humbling.

The villagers would often talk to me about Sister Lucy, the last remaining expatriate missionary at the original Methodist Mission Station at Sasamunga. I never met Sister Lucy, a fellow New Zealander from Morrinsville, but it was clear that the people of Nukiki, and beyond, held her in very high regard. I too admired the courageousness and fortitude of those early missionaries and what they had left behind in small and outlying villages like Nukiki - an island people that had converted to Christianity.

I went back to Nukiki in 1993 and 2006 to visit friends and then again in 2012 to undertake research on village governance. This research showed that while the church remained very influential politically in village life, Nukiki was facing development challenges which were becoming increasingly problematic.

THE LEGITIMACY OF TRADITIONAL SOCIETAL INSTITUTIONS VS THE LEGITIMACY OF THE STATE

Christianity and Christian churches play a crucial role in Solomon Islands. In self-governing rural communities such as Nukiki, governance is distinctly parochial in its application - a hybrid application of chiefly and church authority and quite separate from state governance (Fukuyama 2007; Kabutaulaka 1997). Choiseul (see Figure 1) is geographically, socially, and politically separated from the capital Honiara. In these remote areas the reach of the state is limited, and notions of citizenship and national identity have gained little traction. Instead, in these communities kin group relations underpin society and form the basis of people's identity (Naitoro 2002).

While outposts of the state are found across Choiseul, the ability of the government to exert control in such areas is limited. In fact, Clements and colleagues (2007) maintain that no post-colonial government in Melanesia has ever been able to impose authority over the peripheral outlying areas of their territory. This does not mean that the state is without influence in these areas (see McDougall 2015), rather 'traditional non-state societal institutions are of major importance' (Clements et al. 2007, 49). Predating the state, these traditional structures, such as village elders, headmen, clan chiefs, healers, and religious leaders (see Migdal 1988), have a legitimacy that state institutions have not been able to foster, and this lack of legitimacy tends to further undermine the state and contribute to its fragility. 


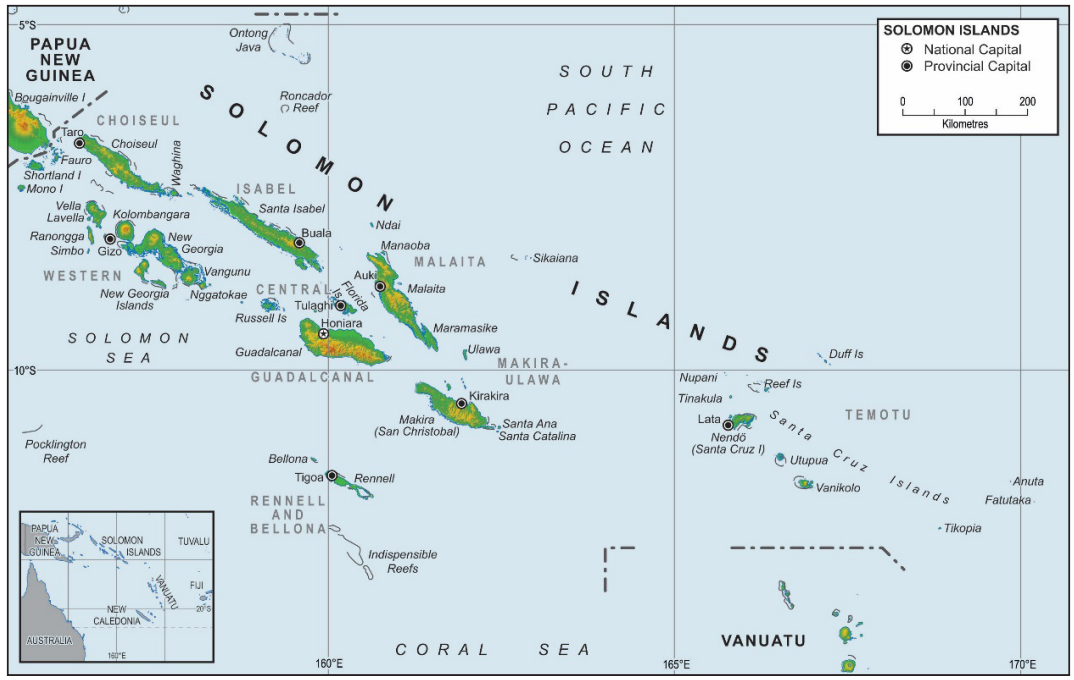

Figure 1. Map of Solomon Islands. (New Zealand Defence Force [NZDF] 2007.)

In the Solomon Islands, eighty-seven per cent of land is customary owned. Customary land tenure is communal, and rights to land are generally vested in descent groups, people who share a common ancestor or ancestor-figure (Allan 1957; Bennett 1987; Larmour 1979). Land-use rights are usually mediated by a big-man or chief, although the degree of power they exercise may differ between areas (Kabutaulaka 2001). Customs regarding land-use rights also vary across groups and can be subject to complex social and religious protocols that have evolved as part of the indigenous epistemology for that area (Gegeo 1998). The physical geography makes communication extraordinarily challenging, and, as a consequence, localised identity has become a predominant feature of Solomon Islands societies (Kabutaulaka 1997). This has resulted in extreme social fragmentation characterised by the existence of numerous language groups (Fukuyama 2007). In such cultures, the concept of personhood is highly relational, and 'understandings of group identity and relations are consistent with understandings of personal identity' (Brigg 2009, 151). Collective identity focused on kin-group relations is, therefore, an important aspect of Solomon Islands society. Indeed, within Solomon Islands society, allegiance is primarily to the kin group, and this is more important than allegiance to the state (Kabutaulaka 1997). 
Choiseul Province is situated in the northwest part of the country and adjacent to Papua New Guinea's Autonomous Region of Bougainville. One of the more remote provinces in Solomon Islands, it is approximately $160 \mathrm{~km}$ in length and is one of the six main islands in the Solomon Islands archipelago (see Figure 2). The population was recorded as 26,372 in the 2009 national census (Solomon Islands Government [sIG] 2009).

Choiseul is administered from Taro, located at the north-western tip of the island. Logistically, this is not an ideal location from which to serve the province. Some logging roads do connect different parts of the island, but these were built primarily for the extraction of logs and quickly fall into disrepair once logging is completed (Choiseul Provincial Government [CPG] 2009). Currently, there are two operational airfields on Choiseul, but for most inhabitants the only feasible transport throughout the province is by sea (CPG 2009; Moore 2007).

Government services and political representation are hampered by this inadequate transport infrastructure. Provincial Government funds are limited, weather-dependent sea transport is unreliable, and equipment is often old or simply broken, making the links between the Provincial Government and dispersed constituent communities quite tenuous. As a result, the myriad of

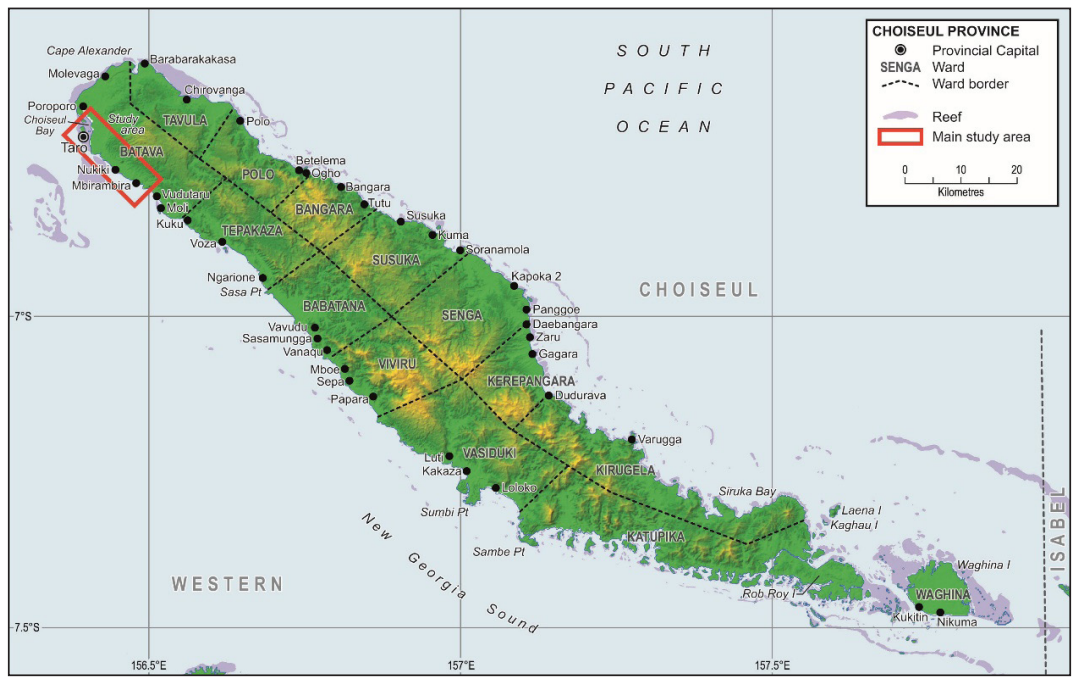

Figure 2. Choiseul Province, showing ward boundaries. (CPG 2009.) 
small villages that comprise Choiseul Province tend to operate independently from the Provincial Government, which, apart from overseeing the village school and occasionally a medical clinic, has little influence on daily village life.

\section{CHALLENGES FACING PROVINCIAL GOVERNMENTS}

Provincial governments, such as Choiseul, have had a chequered past in Solomon Islands. Sanctioned by the Constitution of Solomon Islands (Her Majesty's Government [HMG] 1978) and defined under the Provincial Government Act 1981 (SIG 1981), provincial governments were an attempt to create greater regional autonomy through decentralisation. Provinces were divided into wards (fourteen in the case of Choiseul), and each ward is represented by an elected member. Collectively, these members comprise the Provincial Assembly.

An important aspect of provincial governments was the provision for Area Committees, more commonly known as Area Councils (HMg 1978, 13). The original purpose of Area Councils appears to have been to enable political representation by local chiefs or other local leaders at ward level. ${ }^{4}$ During the processes of rationalisation and centralisation undertaken by the Solomon Islands Government following the 1997 election, another Provincial Government Act (sIG 1997) was introduced. This Act abolished Area Councils, leaving a gap in government at that level (White 2004). In the absence of Area Councils, the only remaining formal points of contact between the ward constituents and the Provincial Government are through the ward member (Hon. J. Kiloe, Premier - Choiseul Province, pers. comm., 25 January 2012) and the ward committees these members constitute, ${ }^{5}$ a link that Cox and Morrison (2004) argue has become increasingly politicised. Nevertheless, interviews undertaken in 2012 with both constituents and the Honourable Member for Batava Ward, in which Nukiki village and Taro are located, revealed that neither seemed overly concerned at the loss of the Area Councils. White (2004) maintains that elimination of these councils reflected the fact that traditional leaders had continued to provide the organisational basis for local governance.

CONTEMPORARY VILLAGE GOVERNANCE IN NUKIKI - CHIEFS AND THE CHURCH

My research on contemporary village governance in Nukiki in 2012 supports White's (2004) view. In villages on Choiseul the chiefs have custodial responsibility for the tribal land as well as the welfare of the members of their tribe. In Nukiki, the chief was well respected, and governance at the tribal level was strong and appeared to work well. Reflecting the transformation that had oc- 
curred in Choiseulese society due to the influence of Christianity, the chief worked in close co-operation with church leaders who represent the other main institution of governance in the village. Across Choiseul there have been many instances where chief and church elder were one and the same person. Such influential leaders had an important role to play in village life. It is, in many respects, artificial to disassemble leadership into separate categories of kastom (tradition) and church, as these effectively merged over the last century. This was certainly the case with Nukiki leadership, where a form of political hybridity had occurred between kastom, as represented by chiefly authority, and the church. This hybrid polity represented the 'traditional non-state societal institutions' referred to by Clements and colleagues (2007) or the 'traditional leaders' referred to by White (2004).

In a large village, such as Nukiki, where several different tribes co-exist, the jurisdiction of the chief is limited to members of his own tribe. Members outside this tribe are the responsibility of their own chief, who is also likely to reside in the village albeit, perhaps, in a separate hamlet. In such villages the church tends to assume overall responsibility for village governance, and in this situation the influence of the church is stronger than that of the chiefs (Hon. J. Kiloe, pers. comm., 13 February 2012).

In 2012 the main United Church building in Nukiki (see Figure 3) was located in Loboro Village, the original mission area and settlement. It was here that the main Sunday morning service was held. A Bishop, who had oversight of the church's Choiseul Region, was also based in Nukiki. The United Church is relatively decentralised and democratic, and includes local, regional, and national organisational structures (McDougall 2008). Nevertheless, over the course of my research in Nukiki, it became clear that there was an inherent weakness in the close association between chiefs and the church. Governance was largely church focused, and according to one chief, 'Nukiki is just concerned about the church. Everything is handled by the church, which takes a lot of their time. They neglect other things' (pers. comm., 6 February 2012). Such sentiments were reflected by other leaders, including the Premier and Deputy Premier, who all talked about a 'crisis of leadership' in villages across Choiseul. Much of this concern centred on larger villages, such as Nukiki, which were multi-tribal in composition. Families could have links to several tribes, thus rendering questions of chiefly authority ambiguous for them. Elsewhere, chiefs had lost the respect of their tribe over charges of unfair distribution of logging royalties. But there were other issues as well: population growth was putting pressure on garden land and raising concerns over sanitation. The sea level was also rising, not only physically threatening coastal settlements, but also causing freshwater 


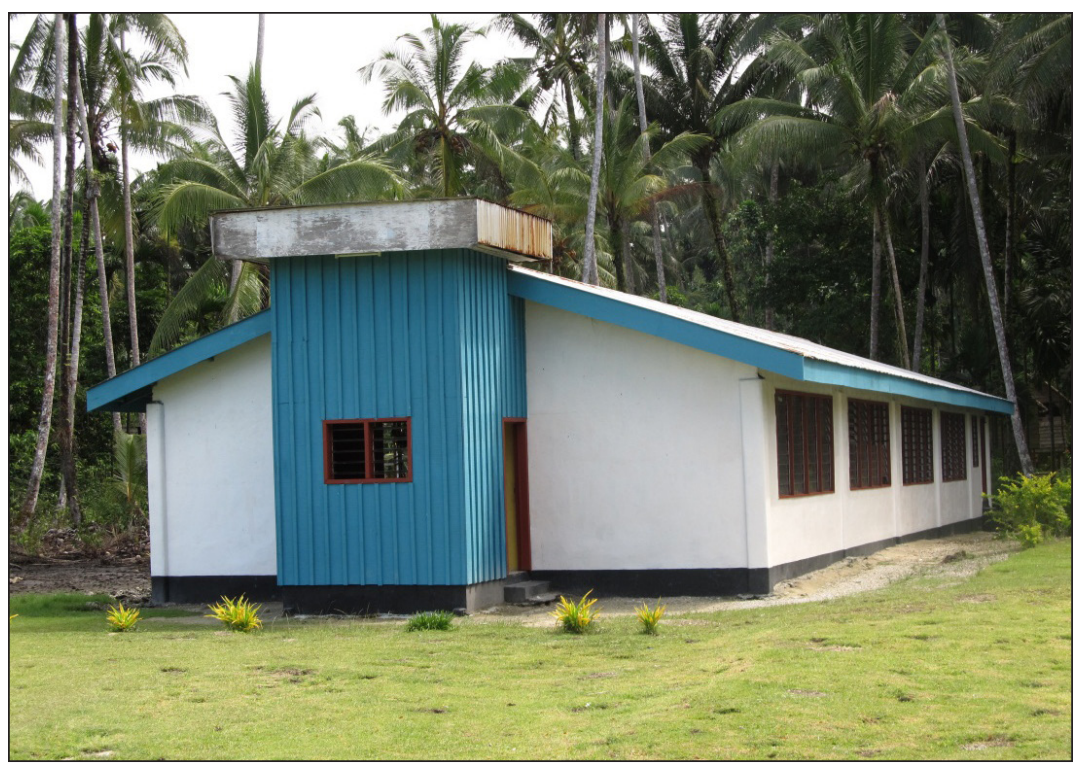

Figure 3. Nukiki United Church, 2012.

streams and wells to become contaminated with saltwater. While acutely aware of these problems, village leaders struggled to offer solutions.

POPULATION, ENVIRONMENTAL, AND DEVELOPMENT CHALLENGES FACING NUKIKI

In 1991 Nukiki comprised ten small hamlets, each having originated as a family settlement that had separated from the original village. Collectively still known as Nukiki, these hamlets were located between mangrove swamps and adjacent coconut plantations, strung out along a narrow coastal terrace and connected by a walking track. The village had a population of only 408 people (Figure 4 ). Most of the buildings were leaf houses made from sago palms. While Nukiki had a primary school, the provincial secondary school was located in Choiseul Bay and had very few places available. Restricted higher education opportunities and limited formal sector employment opportunities meant that most young people expected to stay in the village for most of their lives.

By the time I visited Nukiki in 2006, the village was beginning to change. The hamlet of Tarepasika, where I had lived previously, did not look too different. Leaf houses had been rebuilt, but, essentially, the same peaceful atmosphere 


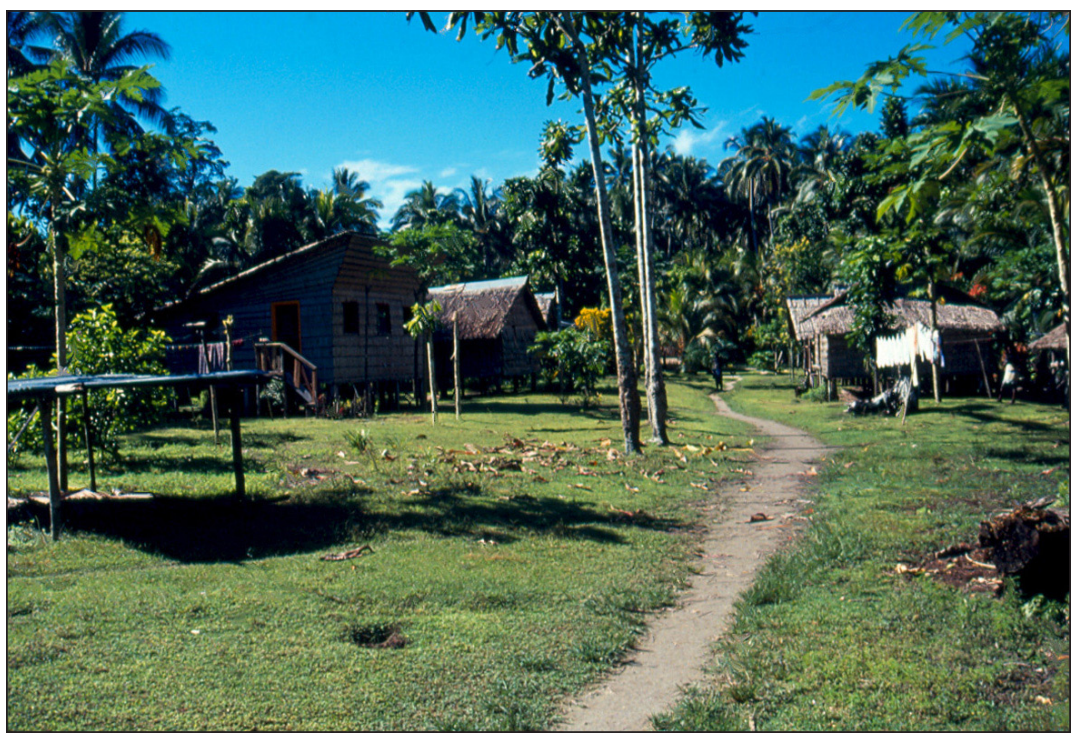

Figure 4. Tarepasika, 1991.

prevailed. The entry point to Nukiki, the mouth of the Talaevondo Stream, was, however, quite different. Heavy seas had scoured it out, something the villagers attributed to sea-level rise (see Figures 5 and 6). ${ }^{6}$

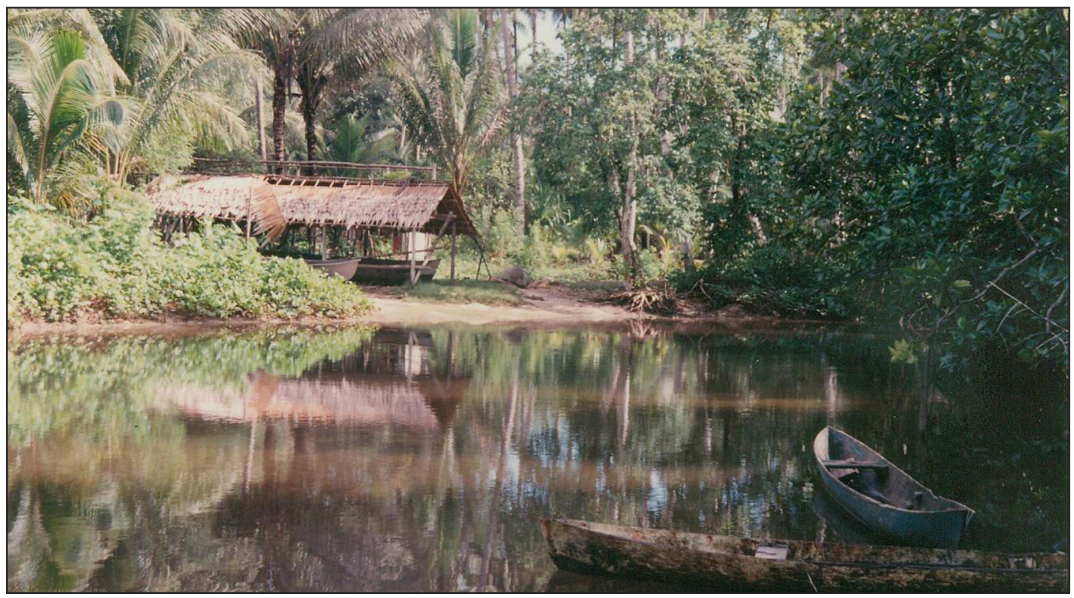

Figure 5. Talaevondo Stream, 1991. 


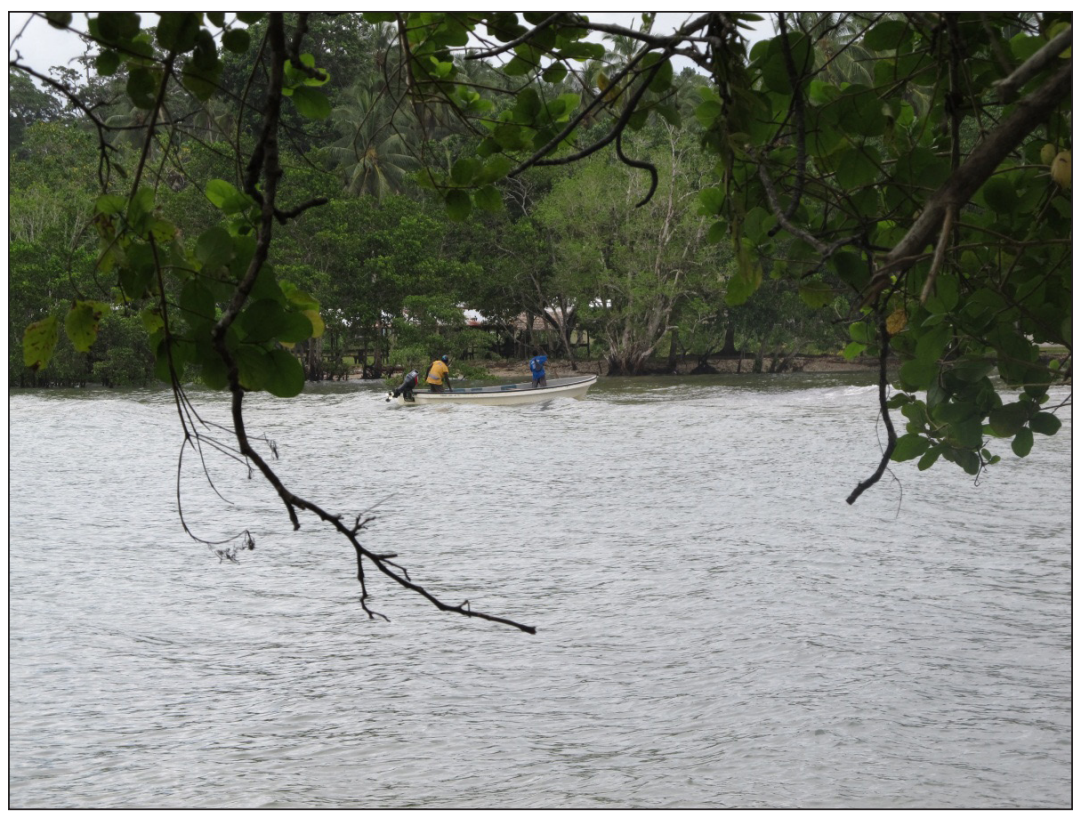

Figure 6. Talaevondo Stream mouth, 2012 - after the tsunami.

Taro, some $8 \mathrm{~km}$ distant, was also making its presence felt in Nukiki. Previously, a very small administrative outpost of Western Province, it had grown significantly once it became a provincial centre in its own right. I had been warned of the 'urban sprawl' that had taken place in Taro but was still surprised at the extent to which this had occurred. More importantly for Nukiki, some villagers were beginning to commute to Taro by canoe for work. This had far-reaching effects. A growing cash economy, and the presence of a nearby urban centre, was influencing village life, and a level of dependency was developing (Cassells 2007; see also Smith 2002). With easy access to services, which were now only a short boat trip away, villagers were becoming less self-reliant (Hon. J. Kiloe, pers. comm., 13 February 2012).

Six years later, when I returned in 2012, wholesale changes in Nukiki were quite apparent (see Figure 7). 2011 census data, recorded by the Pastor of the Nukiki United Church, indicated that the population had grown to 910. The ten hamlets had coalesced into five main settlements: Solovai, Vakatipu, Loboro, Tarepasika, and Karakone. 'Permanent houses', made from sawn timber and corrugated iron, had begun to outnumber leaf houses made from local material. 


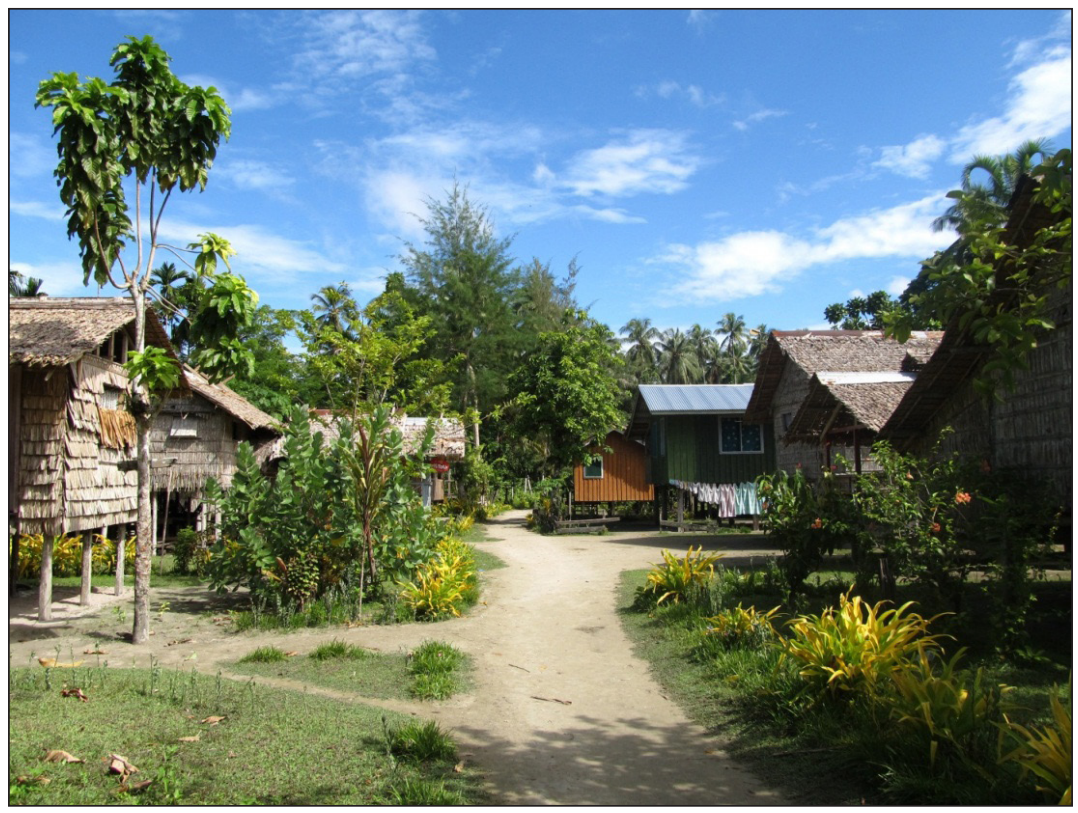

Figure 7. Tarepasika, 2012.

The growth in population has had a significant impact on a number of factors that affect village well-being (see Fazey et al. 2011). Of these, sanitation remains a major challenge, with few latrines being used in the village. ${ }^{7}$ Fresh water supply is also now a growing problem. Unlike 1991, when fresh, drinkable water could generally be obtained from streams, villagers now rely on tanks fed by rainwater from corrugated iron roofs. ${ }^{8}$ This was very convenient and, in their eyes, a sign of development. However, the capacity of the tanks was limited by their small size because they had to be transported to the village by canoe. Thus, drinking water supplies become critical during periods when there is little or no rain. In 2012, no plans existed in the village to address these issues other than to obtain additional water tanks to improve drinking water supplies. ${ }^{9}$ But population growth and further salinisation of the stream due to sea-level rise mean the problems are not going away. Village leadership is not well equipped to deal with such issues, and arguably, some form of external assistance is needed to provide the planning and resources necessary to establish suitable sewage disposal systems and a reticulated tap-water supply. ${ }^{10}$

A shortage of land available for gardening is increasingly becoming a problem. Shifting cultivation (swidden agriculture) is still the main source of food for 
Nukiki. Crops are grown for a period and then, when soil fertility declines, are abandoned and re-established in a newly cleared area of forest. Thus, over time, gardens are moved around the 'forest estate' in a continuous cycle of clearing, burning, crop planting, abandonment, and forest regrowth during a period of fallow (see Macewan 1978; Mitchell 1976; Weightman 1989). The danger with an increasing population is that the fallow period is likely to be reduced by a more frequent cycle of cropping. If this occurs on the limestone karst country typical of the area (Cassells 1992), soil fertility will decline along with garden productivity (Hviding and Bayliss-Smith 2000).

Sea-level rise was an issue that the villagers of Nukiki were very aware of because of the direct impact it was having on them. In 1991 there were no wells in Tarepasika village as drinking water was generally obtained from the Talaevondo Stream (Figure 5). By 2006 I observed a well in Tarepasika as well as a villager's equipment to install it. The well water was used for drinking and washing. In 2012 the well still existed, but the water could no longer be used for drinking because it had become brackish. Furthermore, by 2012 it was no longer possible to drink water from the Talaevondo Stream as it had also become brackish. The villagers attributed these changes to sea-level rise.

The conclusion drawn by the villagers concurs with the findings of the Intergovernmental Panel on Climate Change (IPCC) (2013), which has recorded a global mean sea-level rise between 1993 and 2010 of 3.2 millimetres per year. Published research on sea-level rise in Australia and the Pacific records an even higher sea-level change of +2.87 centimetres for Solomon Islands over a 5.3-year measurement period (Mitchell et al. 2000).

According to the Choiseul Provincial Government Planning Officer, sea-level rise was identified as an issue of high priority by villagers during a Provincial Government village-needs survey (G. Pakipoda, pers. comm., 9 February 2012), and, associated with this, villagers are clearly wanting help from the Provincial Government to secure clean water supplies. ${ }^{11}$ As the sea level continues to rise, it is also possible that some of the more low-lying settlements may need to be relocated at some time in the future.

\section{ECONOMIC DEVELOPMENT AND EDUCATION}

After resisting logging for over twenty years, one tribe in Nukiki, the Siropodoko people, finally allowed the Oceania Trading Company to commence logging on their land in the mid-20oos (see Figure 8). The villagers, I was told, had many meetings over many years, but in the end the chiefs decided to go 


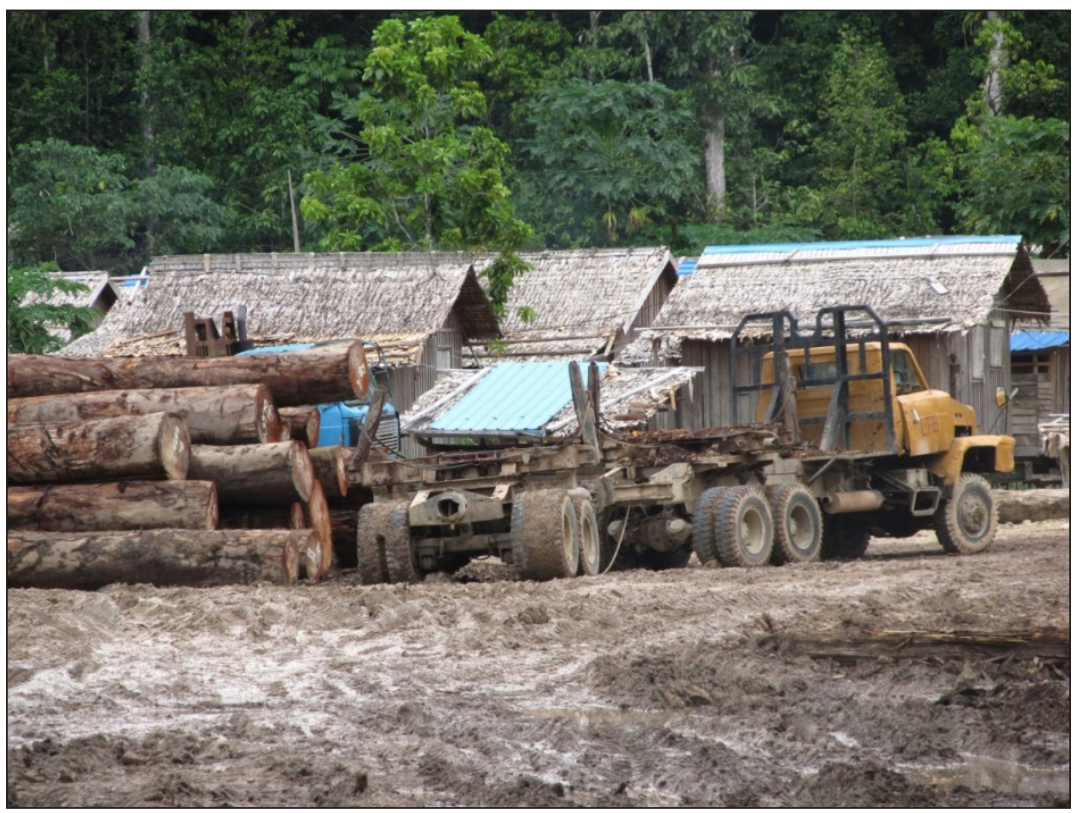

Figure 8. Logging camp at Mbirambira.

ahead with the logging. Once the tribal leaders had decided that they would go ahead and log, the Siropodoko people accepted their decision. However, the matter still remained controversial, and by 2012 most of the disquiet centred on how the royalty payments had been distributed (W. Peni, pers. comm., 28 January 2012).

The saddest thing about the logging at Nukiki is that it has created division within the Siropodoko tribe (B. Savevi, pers. comm., 5 February 2012). As has been the case elsewhere in Solomon Islands following logging, there has been a considerable breakdown in trust, particularly concerning the lack of transparency over royalty payments (see Frazer 1997; Hviding and Bayliss-Smith 2000; Kabutaulaka 2000; Scheyvens and Cassells 1999). One informant told me that 'the (Siropodoko) people were one, now they have become separated' ( $\mathrm{S}$. Zarabule, pers. comm., 22 February 2012). This distrust may, in the long-term, have other ramifications for the Siropodoko people. In other areas some chiefs have lost the respect of their people because they have not distributed logging royalties fairly (Hon. J. Kiloe, pers. comm., 13 February 2012). In such situations it may become difficult for a chief to maintain his authority and to hold his people together. The period after logging may also be challenging. During my 
research it became clear that a post-logging management plan, mandated by the Department of Forestry, Environment and Conservation, had not been prepared. Other than planting some Ngali nut trees and building new classrooms and a clinic, little had been done to utilise logging royalty payments for future development on Siropodoko land.

In regard to education, the Nukiki village primary school is owned and administered by the village school committee. With a roll of 169 children in 2012, the school caters for students from Year One through to Year Six. The school has eight classrooms and a number of teachers' houses. In addition and also administered by the village school committee, a well-housed kindergarten has seventy pre-school children enrolled (L. Soko, pers. comm., 16 February 2012). The Provincial Education Authority supports the village school committee by employing the teachers and channelling grants and government funding to the school. The national government sets the school curriculum and pays the teachers' salaries. According to the Chief Education Officer of Choiseul Province, sixty per cent of the school's funding comes from the national government, thirty per cent from the Provincial Government, and ten per cent from the villagers, who are expected to pay in kind through the provision of materials or involvement in working bees (D. Pitamama, pers. comm., 14 February 2012).

It was clear to me that the villagers of Nukiki took a keen interest in their school, ${ }^{12}$ with significant recent investment in buildings (see Figure 9). By 2012, it was also clear that more children from Nukiki were attending secondary schools and obtaining a tertiary education than had been the case in 1991. ${ }^{13}$ A number of Nukiki young people were now at university, and many more children were travelling away to the community high school at Moli, the provincial secondary school at Choiseul Bay, or to schools beyond. In respect to development, ${ }^{14}$ the increasing frequency with which Nukiki village children were gaining higher levels of education was very encouraging and reflects the national trend whereby expected years of schooling is increasing (United Nations Development Programme [UNDP] 2014). ${ }^{15}$

\section{ENGAGING WITH THE CHURCH}

My research revealed that population growth, development-related issues, and sea-level rise were all impacting on Nukiki village and elsewhere on Choiseul. Collectively, these issues were also contributing to what the Premier of the Province termed a 'leadership crisis' (Hon. J. Kiloe, pers. comm., 13 February 2012). Other senior leaders in Taro and Nukiki spoke of the inability of local leadership to deal with issues such as these, which fall outside the scope of 


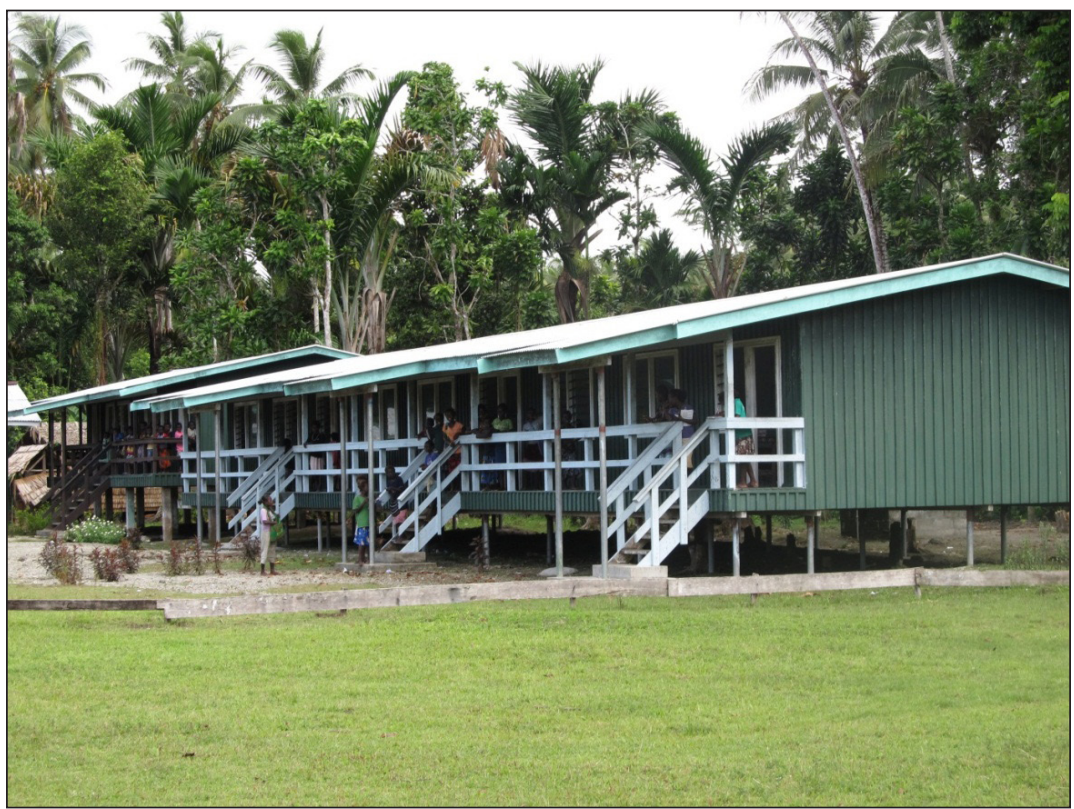

Figure 9. Nukiki village school, 2012.

what Watson-Gegeo and Gegeo (1992) call the 'traditional knowledge system'. Addressing these issues is, however, a necessary precondition if governance at village level is to remain adequate and relevant.

Structural issues, inadequate infrastructure, and, in some instances, a lack of capacity all combine to make it difficult for the Choiseul Provincial Government to provide consistent and reliable services to villages. While, in time, capacity-building initiatives, such as those undertaken through the Provincial Governance Strengthening Programme (UNDP, SIG, and UNCDF 2011), may improve the ability of provincial governments to provide effective services, this will not significantly change the situation in local villages in the short term. Meanwhile the village leaders of Nukiki, in common with many other villages in Choiseul Province, do not have a plan to deal with the increasingly urgent population and development-related challenges that they face. The skills and experience necessary to deal with most of the issues simply do not reside within the village itself. The hybrid alliance of chiefs and the church will need outside assistance to deal with pressing development-related challenges.

Building on their widespread local (and international) legitimacy, churches 
in villages across Solomon Islands are in a strong position to be agents of change, particularly at the village level. In many communities, the church already provides the organisational and governance structure for the village. In large villages where there are many tribes, the church frequently has greater influence than the chiefs and can be the most effective means of relaying information to the village from the Provincial Government. ${ }^{16}$ In liaison with the Provincial Government, the United Church should take on a more active role in facilitating and co-ordinating the development interventions needed to address the challenges faced by villages. There is a strong historical precedent for doing this: the Methodist Mission provided much of the infrastructure for the Western District of Solomon Islands during the colonial period. Furthermore, through the denominational governance structure of sections, circuits, synods, and the national assembly, the United Church has the capacity to link village governance to regional, national, and even international development agencies who could provide the assistance villages urgently need. Strong partnerships between such development agencies, the United Church, and the Provincial Government would provide better co-ordinated development outcomes that would also be acceptable at village level. In essence, the church, not the state, has the 'social licence', networks, and governance structure to effect change at village level.

The concept of forming partnerships to achieve more effective development outcomes is not new. For example, New Zealand's Ministry of Foreign Affairs and Trade (MFAT) relies heavily on New Zealand and offshore partners to deliver its aid programmes, including 'partner country governments, international and regional organisations, other donors, non-government organisations, the private sector and other state sector agencies. MFAT has a policy of investing 'in relationships with partners that deliver high quality services that match' MFAT's 'development priorities' (MFAT n.d., para. 1).

New Zealand-based NGOs, such as Volunteer Service Abroad (vsA), also actively encourage partnerships to achieve specified development outcomes (see vsA n.d.). vsA has, for many years, delivered its in-country programmes through local partner organisations. Volunteer assignments are negotiated with prospective in-country partner organisations, and this results in an 'assignment description' which is used to advertise the volunteer position (see vsa 2018). Once a volunteer has been selected for the position, they are then contracted to the partner organisation through an agreement which specifies the obligations of both parties. As a former vsA Pacific Field Representative (2002-2008), I was responsible for the vSA volunteer programmes in Solomon Islands and Vanuatu. Consequently, I was well aware of the challenges of matching local 
on-the-ground needs with appropriate development inputs from New Zealand. In an effort to improve their recruitment of suitable volunteers and to tap into the knowledge and skills of a wider range of people and organisations, vsA adopted the approach taken by MFAT and began to form partnerships with other New Zealand and regional organisations. By 2018 vsA had agreements with fourteen such partners, which ranged from 'fellow NGOs to large multinational companies and UN agencies' (vsA n.d., 2).

External partnerships that MFAT and vsA utilise are very good in terms of channelling a wide range of expertise into developing country projects or assignments, but, often, what is missing is an effective in-country organisation that can co-ordinate these development inputs. This is especially so where these inputs are required over a range of separate geographic and/or tribal locations. ${ }^{17}$ This is where a church organisation, such as the United Church in Solomon Islands, could help.

As mentioned previously, the United Church of Solomon Islands is relatively decentralised and democratic in its organisational structure. At the national level the church is governed by an Assembly which has its administrative headquarters in Roviana (Munda), but it also has regional and local centres on various other levels and scales. True to its democratic foundation, leaders are elected within the United Church. This represents a significant departure from the way traditional leaders acquire recognition and thus their mandate to lead.

Church meetings are very important in the life of villages such as Nukiki, dealing not only with church-related matters but with most other matters as well. Here, the church provides the venue for village meetings and, through its leaders, has the ability to organise everything within the village. The batu lotu (church leader) is, in effect, the village leader, providing the overall organisational structure for villages such as Nukiki. In reality, the church and the village are practically one body.

In large villages such as Nukiki, it is quite understandable that the church would assume a dominant organisational role. The Methodist Mission deliberately fostered a sense of trans-local identity amongst its adherents that overlaid and extended the exchange networks and alliances that had existed in preChristian times, thereby extending its pastoral reach beyond immediate tribal loyalties (McDougall 2008). In the process it created an effective decentralised and democratic organisational structure that, in time, has proved capable of incorporating most kin groupings or tribes within its geographical sphere of influence. 
Being an independent, democratic, self-governing organisation, the United Church has, in many respects, prepared its people well for citizenship in a modern state. Furthermore, the structures and ideologies of the church align closely with the development and 'good governance' agendas Australia and other influential donors have for Solomon Islands (McDougall 2008). This is significant because denominations such as the United Church are not only substantial and influential, but also viable governing bodies in Solomon Islands. To ignore them would be to render the external development agency blind to the strengths of Solomon Islands society (see Braithwaite et al. 2010). Because social reality at the village level is significantly shaped by societal structures that include the church (see Boege et al. 2009; Naitoro 2002), it seems imperative to engage appropriately with these structures. According to Wesley-Smith (2006, 126), development agencies should seek to 'work with existing institutions and ideologies of governance' rather than only working with partners that 'fit the mould of western style administration'. In short, the church is one potential partner that cannot be ignored. ${ }^{18}$

\section{CONCLUSION}

This paper seeks to encourage development organisations to engage directly with churches in Solomon Islands. Partnerships between a church denomination and external development agencies have the potential to be extremely beneficial. External expertise could be mediated and applied through the local societal institution of the church, creating what Gegeo (1998) terms an 'indigenous epistemology' for that area. For this to happen two challenges must be addressed. First, church denominations, such as the United Church, would need to be convinced that partnering with a development agency would serve the needs of its congregations well. Second, international development agencies would need to overcome reservations they may have about working with religious organisations. If these challenges can be addressed successfully it could provide a strength and legitimacy to local development outcomes that well-meaning external development agencies have often failed to achieve.

\section{NOTES}

1 Ross Cassells worked for the New Zealand Forest Service and New Zealand's Conservation Department before becoming a consultant adviser to the New Zealand Ministry of Foreign Affairs Customary Land Reforestation Project in Solomon Islands. He later joined Volunteer Service Abroad, where he was responsible for the volunteer programmes in Vanuatu and Solomon Islands. Ross also lectured in Environmental Studies and International Relations at IPU New Zealand. His 
Doctorate in Development Studies (Massey University, 2016) examined the hybrid forms of village governance that exist in Choiseul Province, Solomon Islands. Email: rcassells@xtra.co.nz.

2 My roles as a development worker in Solomon Islands include: Adviser to New Zealand Overseas Development Assistance funded Customary Land Reforestation Project - Forestry Extension Section, Solomon Islands Ministry of Forests, Environment and Conservation, 1992-1995, 1999; Commonwealth Development Corporation - social and land tenure survey, North New Georgia - Viru Harbour, Solomon Islands, 1995; Greenpeace NZ - ecoforestry extension adviser, Longgu village, Guadalcanal, Solomon Islands, 1996; Volunteer Service Abroad (vsA) manager of the vsA Solomon Islands Volunteer Programme, 2002-2008.

3 The Methodist Mission to Solomon Islands was first established on New Georgia in 1902 by an Australian, the Reverend Goldie (McDougall 2008).

4 Moore (2004) and White (2004) were a little less specific and maintained that Area Councils were intended to provide local level government representation and, in consultation with the Provincial Government, were responsible for small regions within the province. What the responsibilities of Area Councils were was not, however, defined in the 1981 Act.

5 Other than stipulating the dissolution of Area Assemblies (Area Councils), the 1997 Provincial Government Act (SIG 1997, Section 8 (1)) provided no information on wards nor the manner in which they were to be administered. Whether Ward Committees, such as those that existed in Batava Ward where Nukiki is located, replicated the former Area Councils was not clear. Based on comments from the Premier of Choiseul Province, the administration of wards was likely to be variable and reflect the ability and integrity of the Ward Member and his constituency (J. Kiloe, pers. comm.).

6 By 2006 the shape of the Talaevondo Stream mouth had changed considerably since 1991. The house I had borrowed at Kelekele Point in 1991 no longer sat back from the water's edge but, rather, stood partially in the sea at high tide. The tsunami of 2007 destroyed this house and changed the mouth of the Talaevondo Stream even more (see Figure 6). New areas of saline swamp were also developing around the village as seawater reached further inland at high tide. Some of these changes may also be attributed to the 2007 tsunami, changing weather patterns, and possible seismic events (Mitchell et al. 200o).

7 Although some long-drop toilets did exist in Tarepasika, the mangroves on 
the beach were commonly used as toilet areas, with separate areas set aside for women and men. They were certainly not private, though excrement was washed out to sea and so the areas were not unclean. However, as the population continues to rise, sanitation is likely to become increasingly problematic for the village.

8 Streams are still used for bathing and washing clothes but only at low tide when they are not contaminated with sea water.

9 Although the amount of water collected could have been increased by the use of multiple tanks, I do not recall seeing instances of this. Cost is likely to have been a determining factor.

10 Land ownership disputes may arise as such schemes are likely to utilise or cross land belonging to multiple owners. In a study on social learning through participatory integrated catchment risk assessment on Guadalcanal, Hoverman and colleagues (2011) noted that differing knowledge cultures as well as a lack of familiarity with working collaboratively presented challenges to managing catchment risks such as are now occurring in Nukiki.

11 In 2012 the Choiseul Provincial Government was not in a position to provide this assistance.

12 At a rate of ninety-one per cent for six to fifteen year olds, the school attendance rate in Choiseul was higher than most other provinces (SIG 2009).

13 In 1991 very few places were available in the one secondary school that existed on Choiseul, so higher education opportunities for village children were severely restricted (Cassells 1992).

14 The 1990 UndP Human Development Report (UNDP 1990, 10) defines human development as 'the process of widening people's choices and the level of their well-being. This definition is based on conceptual work by Amartya Sen (1979) where agency, empowerment, and freedom are considered necessary for individuals to function as they desire. Commonly termed the human development and capability approach', this approach 'has become a major paradigm in secular development scholarship' (Hasu 2018, 390).

15 The Undp Human Development Report (2014) for Solomon Islands noted that expected years of schooling had increased from 6.0 in 1990 to 9.2 in 2012.

16 The Premier of Choiseul noted to me that he often found it more effective to 
relay information to the village through church leaders than through the chiefs (pers. comm., 13 February 2012).

17 For example, in addressing similar issues arising from sea-level rise in different semi-autonomous Solomon Islands provinces.

18 The debate concerning the nexus of religion, politics, and development is still relatively new (Bush, Fountain, and Feener 2015). This, however, creates what Smith $(2017,64)$ describes as a 'common space for religious and secular actors to explore together what development is and what it should be. Bush, Fountain, and Feener $(2015,2)$, for example, suggest 'building alliances and establishing broad movements that work together' to achieve improvements in health and education, and reductions in poverty. Including religious and other social institutions in such networks is seen as an important means of creating and enhancing capabilities and improving development indicators (Bush, Fountain, and Feener 2015; Hasu 2018).

\section{REFERENCES}

Allan, Colin H. 1957. Customary Land Tenure in the British Solomon Islands Protectorate. Honiara: The Western Pacific High Commission.

Bennett, Judith A. 1987. Wealth of the Solomons: A History of a Pacific Archipelago, 1800-1978. Honolulu: University of Hawaii Press.

Boege, Volker, Anne Brown, Kevin Clements, and Anna Nolan. 2009. 'Building Peace and Political Community in Hybrid Political Orders'. International Peacekeeping 16 (5):599-615.

Braithwaite, John, Sinclair Dinnen, Matthew Allen, Valerie Braithwaite, and Hilary Charlesworth. 2010. Pillars and Shadows: Statebuilding as Peacebuilding in Solomon Islands. Canberra: ANU E Press.

Brigg, Morgan. 2009. 'Wantokism and State Building in Solomon Islands: A Response to Fukuyama'. Pacific Economic Bulletin 24 (3):148-161.

Bush, Robin, Philip Fountain, and R. Michael Feener. 2015. 'Introduction'. In Religion and the Politics of Development, edited by Philip Fountain, Robin Bush, and R. Michael Feener, 1-10. Hampshire: Palgrave Macmillan.

Cassells, Ross M.1992.'The Valuation of Subsistence Use of Tropical Rainforest on 
the Island of Choiseul, Solomon Islands: A Comparison between Subsistence Values and Logging Royalties'. MPhil diss., Massey University.

- 2007. 'Nukiki Revisited'. vISTA (vSA Magazine), 32-33.

- 2016. 'Custom, Governance and Westminster in Solomon Islands: Charting a Course Out of the Political Quagmire'. PhD diss., Massey University.

Choiseul Provincial Government. 2009. Choiseul Province Medium Term Development Plan 2009-2011. Taro: Choiseul Provincial Government.

Clarke, Matthew. 2015. 'Innovative Delivery Mechanisms: Australian Aid Partnership with Churches in Papua New Guinea'. Journal of International Development 27 (8):1462-1478.

Clements, Kevin P., Volker Boege, Anne Brown, Wendy Foley, and Anna Nolan. 2007. 'State Building Reconsidered: The Role of Hybridity in the Formation of Political Order'. Political Science 59 (1): 45-56.

Cox, John, and Joanne Morrison. 2004. Solomon Islands Provincial Government Information Paper. Canberra: AusAID.

Fazey, Ioan, Nathalie Pettorelli, Jasper Kenter, Daniel Wagatora, and Daniel Schuett. 2011. 'Maladaptive Trajectories of Change in Makiar, Solomon Islands'. Global Environmental Change 21 (4):1275-1289.

Fountain, Philip, Robin Bush, and R. Michael Feener. 2015. 'Religion and the Politics of Development'. In Religion and the Politics of Development, edited by Philip Fountain, Robin Bush, and R. Michael Feener, 11-34. Hampshire: Palgrave Macmillan.

Frazer, Ian. 1997. 'The Struggle for Control of Solomon Islands Forests'. The Contemporary Pacific 9 (1):39-72.

Fukuyama, Francis. 2012 [2007]. 'Observations on State-Building in the Western Pacific'. Advances in Civil and Structural Engineering 10: 658-672.

Gegeo, David W. 1998. 'Indigenous Knowledge and Empowerment: Rural Development Examined from Within'. The Contemporary Pacific 10 (2):289-315.

Hasu, Päivi. 2018. 'Faith-based Development of World Vision Tanzania'. Journal of 
Contemporary Religion 33 (3):389-406.

Her Majesty's Government. 1978. Constitution of Solomon Islands, 1978 No. 783 Stat. (1978 7 July 1978).

Hoverman, Suzanne, Helen Ross, Terence Chan, and Bronwyn Powell. 2011. 'Social Learning through Participatory Integrated Catchment Risk Assessment in Solomon Islands'. Ecology and Society 16 (2):1-17.

Hviding, Edvard, and Tim Bayliss-Smith. 2000. Islands of Rainforest: Agroforestry, Logging and Eco-tourism in Solomon Islands. Aldershot: Ashgate.

Intergovernmental Panel on Climate Change. 2013. Climate Change 2013: The Physical Science Basis. Contribution of Working Group 1 to the Fifth Assessment Report of the Intergovernmental Panel on Climate Change. Cambridge: IPCC.

Kabutaulaka, Tarcisius T. 1997. 'Deforestation and Politics in Solomon Islands. In Governance and Reform in the South Pacific, edited by Peter Lamour, 117-145. Canberra: National Centre for Development Studies, Australian National University.

. 2000. 'Rumble in the Jungle: Land, Culture and (Un)Sustainable Logging in Solomon Islands'. In Culture and Sustainable Development in the Pacific, edited by Anthony Hooper, 88-97. Canberra: National Centre for Development Studies, Australian National University.

- 2001. 'Paths in the Jungle: Landowners and the Struggle for Control of Solomon Islands' Logging Industry'. PhD diss., Australian National University.

Larmour, Peter, ed. 1979. Land in the Solomon Islands. Suva: University of the South Pacific; Honiara: Ministry of Agriculture, Solomon Islands.

Macewan, J.M. 1978. Subsistence Agriculture. Port Moresby: Department of Primary Industry.

Marshall, Katherine. 2001. 'Development and Religion: A Different Lens on Development Debates'. Peabody Journal of Education 26 (3-4):339-375.

McDougall, Debra. 2008. 'Religious Institutions as Alternative Structures in Postconflict Solomon Islands?: Cases from Western Province'. State, Society and Governance in Melanesia Discussion Paper. Canberra: Australian National 
University.

- 2015. 'Customary Authority and State Withdrawal in Solomon Islands: Resilience or Tenacity?' The Journal of Pacific History 50 (4):450-472.

Migdal, Joel S. 1988. Strong Societies and Weak States: State-Society Relations and State Capabilities in the Third World. Princeton, NJ: Princeton University Press.

Ministry of Foreign Affairs and Trade. n.d. 'New Zealand Ministry of Foreign Affairs and Trade: Our Partners'. Accessed 20 May 2019 from https://www. mfat.govt.nz/en/aid-and-development/our-approach-to-aid/our-partners/

Mitchell, Donald D. 1976. Land and Agriculture in Nagovisi, Papua New Guinea. Boroko: Institute of Applied Social and Economic Research.

Mitchell, W., J. Chittleborough, B. Ronai, and G.W. Lennon. 200o. 'Sea Level Rise in Australia and the Pacific'. The South Pacific Sea Level and Climate Change Quarterly Newsletter 5(1):10-19.

Moore, Clive. 2004. Happy Isles in Crisis: The Historical Causes for a Failed State in Solomon Islands 1998-2004. Canberra: Asia Pacific Press.

- 2007. 'External Intervention: The Solomon Islands beyond RAMsi'. In Security and Development in the Pacific Islands: Social Resilience in Emerging States, edited by M. Anne Brown, 169-196. Boulder: Lynne Rienner.

Naitoro, John. 2002. 'Articulating Kin Groups and Mines: The Case of the Gold Ridge Mining Project in the Solomon Islands'. PhD diss., Australian National University.

New Zealand Defence Force. 2007. 'Map of Solomon Islands'. Wellington: New Zealand Defence Force.

Scheyvens, Regina, and Ross M. Cassells. 1999. 'Logging in Melanesia. In Strategies for Sustainable Development: Experiences from the Pacific, edited by John Overton and Regina Scheyvens, 109-124. London: Zed Books.

Sen, Amartya. 1979. 'Equality of What?' In Tanner Lectures on Human Values, Volume 1, edited by Sterlinh M. McMurrin, 195-220. Salt Lake City: University of Utah Press. 
Smith, Jonathan D. 2017. 'Positioning Missionaries in Development Studies, Policy and Practice'. World Development 90:63-76.

Smith, Michael F. 2002. Village on the Edge: Changing Times in Papua New Guinea. Honolulu: University of Hawai'i Press.

Solomon Islands Government. 1981. The Provincial Government Act, No. 7 of 1981, Stat. (1981).

- 1997. The Provincial Government Act of 1997, No. 7 of 1997, Stat. (1997).

-2009. Choiseul: Provincial Profile of the 2009 Population and Housing Census. Honiara: National Statistics Office.

United Nations Development Programme. 1990. Human Development Report 1990. New York: Oxford University Press.

- 2014. Human Development Report 2014: Solomon Islands. New York: United Nations Development Programme.

UNDP, SIG, and UNCDF. 2011. National Provincial Governance Strengthening Programme. Guidelines and Reporting Formats for the Provincial Capacity Development Fund (PCDF) Annual Performance Assessment. Honiara: Government of the Solomon Islands.

Ver Beek, Kurt A. 200o. 'Spirituality: A Development Taboo'. Development in Practice 10:31-43.

Volunteer Service Abroad. 2018. 'Business Development Adviser (Shipyard)'. Accessed 20 May 2019 from https://vsa.org.nz/volunteer/volunteer-vacancies/ business-development-adviser

_. n.d. 'Partner with vsA'. Accessed 20 May 2019 from https://vsa.org.nz/ support-us/partner

Watson-Gegeo, Karen, and David W. Gegeo. 1992. 'Schooling, Knowledge, and Power: Social Transformation in the Solomon Islands'. Anthropology and Education Quarterly 23(1):10-29.

Weightman, Barry. 1989. Agriculture in Vanuatu: A Historical View. Cheam: The British Friends of Vanuatu. 
Article $\cdot$ Cassells

Wesley-Smith, T. 2006. 'There Goes the Neighbourhood: The Politics of Failed States and Regional Intervention in the Pacific'. In Redefining the Pacific?: Regionalism Past, Present and Future, edited by Jenny Bryant-Tokalau and Ian Frazer, 121-126. Burlington: Ashgate.

White, Geoffrey. 2004. Traditional Leadership Report. Honiara: UNDP-sIg Isabel Province Development Project. 